\title{
Erratum to: Lead Exposure: A Contributing Cause of the Current Breast Cancer Epidemic in Nigerian Women
}

\author{
Olusegun I. Alatise • Gerhard N. Schrauzer
}

Published online: 25 August 2010

(C) Springer Science+Business Media, LLC 2010

\section{Erratum to: Biol Trace Elem Res (2010) 136:127-139 DOI 10.1007/s12011-010-8608-2}

The original version of this article unfortunately contained mistakes.

Page 131, Discussion section under Associations with Individual Elements, line 3 from bottom: '...2.2 $-21 \mu \mathrm{g} / \mathrm{dL}$ ' should read $2.2-14 \mu \mathrm{g} / \mathrm{dL}$.

Table 4, last column, Range for $\mathrm{Cu}$ should read $0.32-44.7 \mu \mathrm{g} / \mathrm{g}$.

The online version of the original article can be found at http://dx.doi.org/10.1007/s12011-010-8608-2.

O. I. Alatise

Department of Anatomy and Cell Biology, College of Health Sciences, Obafemi Awolowo University, Ile-Ife, Nigeria

e-mail: segunalatishe@yahoo.co.uk

G. N. Schrauzer $(\bowtie)$

Department of Chemistry and Biochemistry, University of California, San Diego, CA, USA

e-mail: gschrauzer@ucsd.edu 